\title{
Review \\ METEOROLOGICAL FACTORS AND ASIAN SOYBEAN RUST EPIDEMICS - A SYSTEMS APPROACH AND IMPLICATIONS FOR RISK ASSESSMENT
}

\author{
Emerson Medeiros Del Ponte ${ }^{1 *}$; Paul David Esker ${ }^{2}$ \\ ${ }^{1}$ UFRGS/Faculdade de Agronomia - Depto. de Fitossanidade, C.P. 15100 - $90001-970$ - Porto Alegre, RS - Brasil. \\ ${ }^{2}$ University of Wisconsin - Dept. of Plant Pathology, 53706, Madison, WI - U.S.A. \\ *Corresponding author <emerson.delponte@ufrgs.br>
}

\begin{abstract}
Favorable meteorological and environmental conditions are critical components that affect Asian soybean rust (ASR), caused by Phakopsora pachyrhizi, the most damaging fungal disease of soybean. In this review, we used available knowledge on the effect of meteorological factors affecting the disease to construct a systems-based approach to understand the risk of ASR epidemics. The systems approach is based on a hierarchical framework where relevant environmental factors that affect the key stages of the ASR disease cycle are identified and this included both aerobiological and epidemiological components. The formal framework we used examined the following epidemic characteristics: spore release, spore dispersal, spore deposition, infection efficiency, latent period and spore production. It provided the ability to identify the most important meteorologicalrelated factors along with relevant knowledge gaps from which the implications for disease forecasting were described. This is new information that can be used as a guide for further epidemiological research and especially to develop and improve upon both local and regional risk models.

Key words: Phakopsora pachyrhizi, plant epidemiology, risk prediction, climatology, plant diseases
\end{abstract}

\section{FATORES METEOROLÓGICOS E AS EPIDEMIAS DE FERRUGEM ASIÁTICA - UMA ABORDAGEM SISTÊMICA EIMPLICAÇÕES NA AVALIAÇÃO DE RISCO}

\begin{abstract}
RESUMO: Condições meteorológicas e ambientais são componentes críticos nas epidemias de ferrugem asiática da soja (FAS), doença causada pelo fungo Phakopsora pachyrhizi e que causa o maior dano na cultura da soja. Nesta revisão, o conhecimento sobre o efeito de fatores meteorológicos que influenciam nas epidemias foi usado para construir uma abordagem sistêmica para compreender o risco de epidemias de FAS. Esta é baseada em uma estrutura hierárquica onde os fatores relevantes que afetam os estágios chave no ciclo da doença foram delineados, incluindo os componentes aerobiológicos e epidemiológicos. As seguintes características epidemiológicas foram avaliadas: liberação de esporos, dispersão de esporos, deposição de esporos, eficiência de infecção, período latente e produção de esporos. O conhecimento sobre os fatores meteorológicos que afetam cada um dos componentes foi revisado, sendo identificados os fatores mais importantes e as falhas de conhecimento, bem como as implicações para a previsão da doença. A informação é importante para orientar a pesquisa epidemiológica futura e especialmente desenvolver e melhorar modelos de risco da doença em níveis locais a regionais.

Palavras-chave: Phakopsora pachyrhizi, epidemiologia de plantas, previsão de risco, climatologia, doenças de plantas
\end{abstract}

\section{INTRODUCTION}

Asian soybean rust (ASR) is worldwide among the most damaging diseases of soybean (Glycine max L.). The disease is caused by the fungus Phakopsora pachyrhizi Syd. \& P. Syd, an obligate parasitic fungus that was first reported in Asia in 1902 (Bromfield,
1984) and has since become endemic and able to cause yield reductions up to $80 \%$ without the application of an adequate control measure (Sinclair \& Hartman, 1999). In 2001, ASR was first found in the Americas, from where it rapidly spread into the major world soybean regions of Brazil (Yorinori, 2002), Argentina (Rossi, 2003) and the United States (Schneider et al., 
2005) over subsequent growing seasons. Previous reports prior to 2001 of soybean rust in Brazil and Central America appear to be related to another Phakopsora fungus, Phakopsora meibomiae (Ono et al., 1992).

Since its introduction into Brazil, ASR has had a great negative economic effect on soybean production. Yearly economic losses due to ASR, since the 2003/04 cropping season, have been estimated to be above US\$ 2 billion (Consórcio Antiferrugem, 2007). Empirical evidence indicates that the majority of the Brazilian regions are favorable for ASR establishment and both severe epidemics and crop losses have been reported in the absence of an effective disease control (Yorinori et al., 2005). Nevertheless, the year-toyear economic impact is quite variable across Brazil's soybean production regions (Consórcio Antiferrugem, 2007). In the United States, ASR epidemics have been primarily limited to the Southern Gulf States and have shown a slow northward movement into major production regions (Christiano \& Scherm, 2007). There has not been reports on negative economic effects due to ASR in the United States, and although yield reductions of up to $33 \%$ have been documented in untreated control experiments in Georgia (Kemerait et al., 2006), it is still uncertain to what extend such losses will occur on a regional or continental scale across the United States. In Argentina, ASR epidemics occur every season but the disease is typically found late enough during the growing season that significant yield loss has been mostly limited to some northern locations in that country (Ivancovich, 2005).

The marked difference in the effects of ASR among the three countries (Argentina, Brazil and the United States) appears to be related to unique characteristics in Brazil that increase its risk to ASR. First, year-round survival of $P$. pachyrhizi is much more likely to happen in Brazil than in either the U.S. or Argentina. In those two countries, inoculum is only likely to survive in either the southern (United States) or northern (Argentina) regions, due to cold stresses during the winter at higher latitudes (Pivonia \& Yang, 2004). However, although ASR has been found during the winter in volunteer soybean plants in Argentina (Ivancovich, 2005) and in kudzu early spring in southern U.S. (Sconyers et al., 2006), these small and scattered inoculum sources might be a reason for epidemics in the subsequent growing season. When considering the very favorable seasonal tropical climate in regions such as the Brazilian Cerrados and sub-tropical Southern Brazil, with higher rainfall during the summer, the risk for substantial ASR yield losses is higher compared to Argentina and the United States.

Currently, the only effective control of ASR is through the use of single or sequential fungicide sprays depending on the disease pressure (Godoy, 2005; Levy, 2005; Sconyers et al., 2006), but long-term effectiveness may be reduced because of the considerable increase in production costs and the potential ineffectiveness of host resistance under high ASR pressure, as well as the variable efficiency of the different fungicides (Godoy, 2005). Current soybean cultivars lack in resistance or tolerance to reduce damage by ASR and cultural practices have proven to be limited for managing the disease (Yorinori et al., 2005).

A critical component for assessing and managing ASR risk is through an improved understanding of the disease epidemiology. Such studies enable the identification and quantification of the key factors that drive an ASR epidemics and subsequent yield losses, thus providing a rational basis to improve disease management. ASR epidemics result from the interaction of factors that form a fairly complex system. Current knowledge of ASR has combined previous epidemiological research based on data from Asian countries (Yang, 1977) and Australia (Casey, 1981) with a considerable amount of new information generated in more recent years. Going back to the early 1970's, there has been great concern that ASR would adversely affect soybean production in the United States, and thus, several studies were initiated in that country using containment facilities. Those studies helped to increase the understanding of the biology of P. pachyrhizi and the environmental requirements necessary for ASR (Marchetti et al., 1976; Melching et al., 1979). A major step forward in increasing epidemiological knowledge of ASR was based on a cooperative agreement between the U.S. and Taiwan, where an extensive sequential planting experiment in Taiwan helped to shed light on the disease epidemiology under natural conditions at plot and field scales (Tchanz, 1984; Yang et al., 1990). Those studies provided detailed information that was used to develop first epidemiological models aimed to understand and assess the risk of the disease and potential losses in the United States (Yang et al., 1991a, 1991b).

Recently, there has been a surge in new epidemiological studies for ASR because of the urgent need to accurately predict and manage the disease across such a large geographical area. As a consequence, several disease models have been developed to assess and predict the risk of the disease at various geographical scales (Del Ponte et al., 2006a). A common feature of most ASR models is the integration of meteorological data as predictors because there is a large body of research that has demonstrated that single processes in the fungal life cycle (Melching et al., 1989) as well as epidemic dynamics ranging from a field to a continental scale are strongly influenced by environmental conditions (Del Ponte et al., 2006b). 
In this review our objective was to synthesize published information on the meteorological and environmental factors that affect both aerobiological and epidemiological components of ASR using an integrated systems approach that links basic components of the disease cycle. Also, a discussion of the key environmental variables is presented, and relevant knowledge gaps are identified that may directly affect future research. By identifying gaps regarding ASR, the development and improvement of risk models, especially for regional large-scale models that consider the hierarchical nature of ASR epidemics and that determine what the effect of scaling up or down predictions at different scales may be will help improve longterm ASR risk assessment.

\section{EPIDEMIC COMPONENTS}

There are several factors to consider when understanding a soybean rust epidemic. Essentially, they relate to each component in the classic disease triangle - host, pathogen and environment; all components interactively influence the disease complex and dynamic nature of the disease. Clearly, empirical evidence has shown that amongst the epidemic components, the environmental conditions, essentially driven by specific meteorological factors have a greater role in understanding ASR epidemiology (Marchetti et al., 1976; Bromfield, 1984; Tchanz et al., 1984). Often, meteorological factors directly or indirectly affect both hostand pathogen-specific factors, thus resulting in complex interactions. Specific environmental conditions provide a stimulus and response of the fungus at specific stages of its life cycle both in its aerobiological and epidemiological (parasitic) stages.

Overview of the disease cycle - As an obligate parasite, the primary inoculum for $P$. pachyrhizi consists of infected soybean plants or other live hosts that harbor the spores in their uredial stage. To initiate the aerobiological phase, the fungal spores need to be released from the uredias and escape from the canopy. These spores are then transported in the atmospheric boundary layers and may be deposited onto other crops, potentially leading to a new parasitic phase. Under favorable conditions, infection begins when the germ tube elongates from the spore and forms an appressoria that has a hyphal tube on its bottom part, enabling direct penetration of the underlying epidermal cells. A few days post-infection, necrosis of soybean tissues in and around the penetration site occurs. Uredias are formed mostly on the lower side of the leaf and within this necrotic zone, but only a small portion of the lesion area $(<15 \%)$ is comprised of sporogenous tissue (Melching et al., 1979). Uredias are formed continuously for approximately three to seven weeks, and spores are produced for approximately three weeks (Marchetti et al., 1975). A telial stage of the fungus may form at very specific conditions but its germination ability and role in the disease cycle is largely unknown (Bromfield, 1984). Figure 1 presents the successive events on the disease cycle including aerobiological and epidemiological components, affected by meteorological factors that will be discussed further.

\section{METEOROLOGICAL FACTORS AFFECTING AEROBIOLOGICAL COMPONENTS}

P. pachyrhizi spores, similar to many other fungi, are capable of movement in the atmosphere over long distances from one geographic location to another (Gregory, 1973). The different components of an aerobiological model system (preconditioning, takeoff, horizontal transport, descent and landing, and impact) are strongly influenced by both ecological and environmental factors. P. pachyrhizi spores proceed through all stages of the aerobiological process, but while variables that govern some of the processes have been well studied, others have substantial knowledge gaps (Isard et al., 2005).

Spore release and canopy escape - Release of spores from the uredias occurs by passive means since the fungus does not have an active mechanism of spore liberation. According to Isard et al. (2005), very little is known about which and how environmental factors influence the release of $P$. pachyrhizi spores from the canopy into the atmosphere. Wind and turbulence seem to be critical factors for entraining fungal spores and lifting them out of the canopy. Recently, it has been suggested that the rainfall (Del Ponte et al., 2006b) could be related to the release of $P$. pachyrhizi spores, among other effects. This would link to what Melching et al. (1979) documented, in which P. pachyrhizi spores tended to clump and stick together, and then rain splash could facilitate dislodgement of spores from the uredias. Direct evidence of this phenomenon, however, is lacking.

While it has been documented that clouds of spores usually escape from infected fields, the majority of spores either land on the same crop canopy or on the ground within the canopy (Aylor, 1986). Only those spores that escape the canopy into the faster moving air above can contribute to the long distance spread of disease (Aylor \& Ferrandino, 1985). Zidek (2007) observed that characteristics of the soybean canopy and leaf area index were key factors for predicting P. pachyrhizi spore release. The study showed that an open soybean canopy allowed more rust spores to escape (average of $26 \%$ of spores escaped) compared with closed canopies (average of approximately $10 \%$ of spores escaped). 


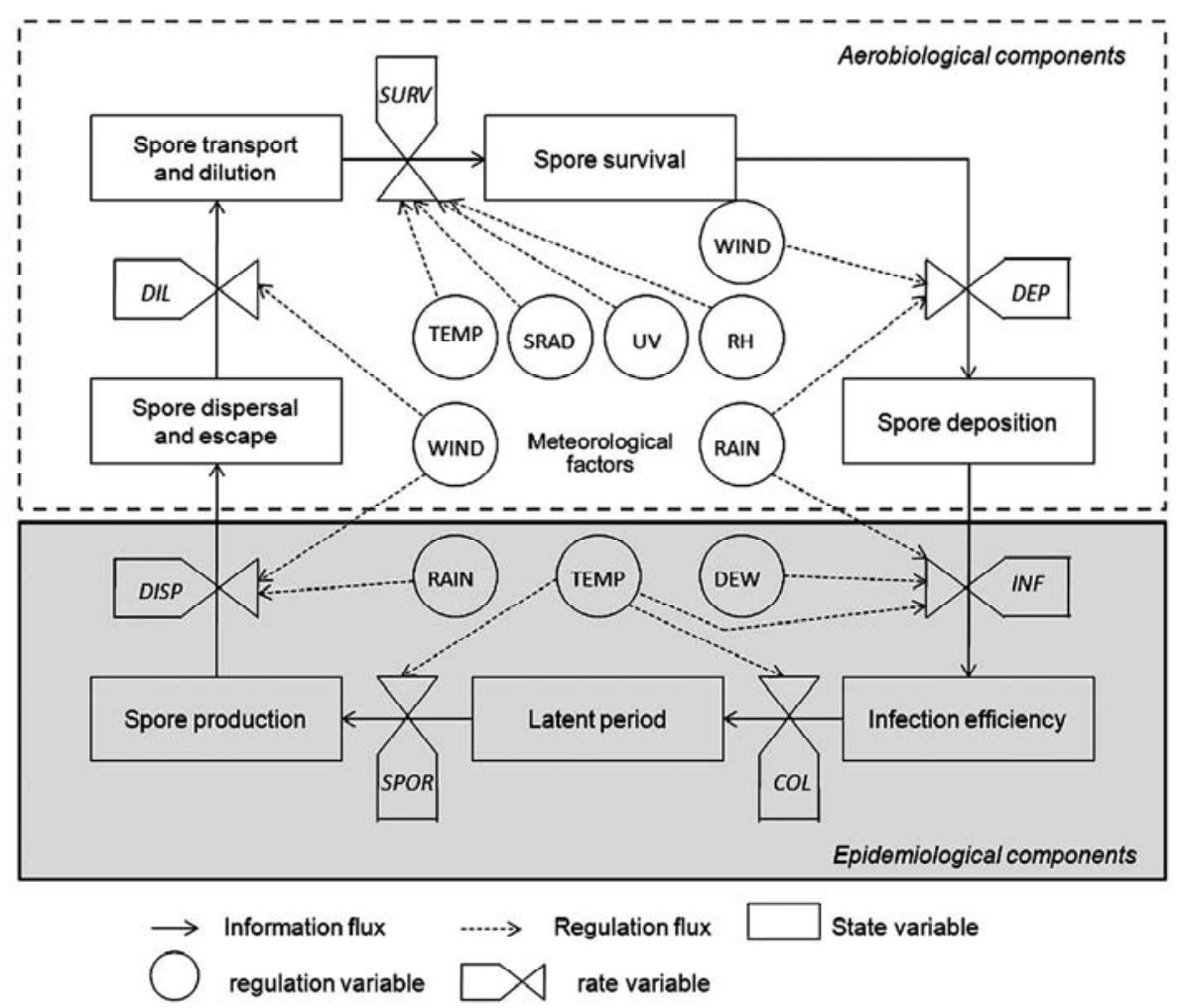

Figure 1 - Components of the epidemiological and aerobiological phases of Phakopsora pachyrhizi causing Asian soybean rust. State variables are named for each component. Rate variables for the aerobiological phase are presented for spore dispersal (DISP), dilution of spores in the atmosphere $(D I L)$, survival of spores while airborne $(S U R V)$, and deposition of spores over land surfaces. Rate variables for the epidemiological phase are presented for infection (INF), colonization $(C O L)$ and sporulation $(S P O R)$ in the crop tissues. Key meteorological factors affecting each state variable are indicated: temperature (TEMP), rainfall (RAIN), dew (DEW), relative humidity (RH), wind (WIND), solar radiation (SR), and ultra violet light (UV).

A preliminary study on the release and dispersal of soybean rust spores produced at reproductive stages of soybean development were monitored using rotorod samplers and passive traps (Beck et al., 2006). Based on that sampling, ASR spores were detected in a typical pattern of spore release and escape over the course of a day. During the morning, and before dew dried out, spore release was minimal, increased after leaves had dried and peaked around midday, before tapering off in the evening period. Furthermore, rainfall events appeared to drastically reduce spore release for a 24- to 48-h period (Beck et al., 2006). Isard et al. (2005) has stated the role of other environmental factors including daylight, temperature, and humidity may affect the timing of spore release, but to date, quantitative information regarding these factors is lacking.

Spore dispersal in the atmosphere and survival while airborne - After escaping the soybean canopy, P. pachyrhizi spore clouds are taken up by air currents and diluted in the atmosphere by turbulent diffusion and wind shear during the transport (Isard et al., 2005). While airborne, fungal spores survival is strongly affected by other environmental variables, including tem- perature, solar radiation, ultraviolet radiation, and relative humidity. Kochman (1979) exposed fresh $P$. pachyrhizi uredospores for 8 hours at a range of temperatures from 11 to $42.5^{\circ} \mathrm{C}$ to determine spore survival. After exposure, uredospores were germinated on $0.2 \%$ water agar for either 4 or 16 hours at $21^{\circ} \mathrm{C}$. Approximately $10 \%$ germination was observed when uredospores were exposed to $28.5^{\circ} \mathrm{C}$, compared to an average of $50 \%$ germination when exposed to lower temperatures. Based on reduced viability of spores that were incubated at high temperatures, Kochman (1979) indicated that high daytime temperatures could be detrimental for ASR spore survival. Recently, the effects of sunlight (both total solar and ultraviolet irradiance measurements) on spore survival were used to predict P. pachyrhizi spore germination (Isard et al., 2006). The authors found that uredospores exposed to doses of solar and ultraviolet (UV) radiation of $28 \mathrm{MJ} \mathrm{m}^{-2}$ and $1 \mathrm{MJ} \mathrm{m}^{-2}$, respectively, did not germinate. The proportion of relative germination (with respect to the germination proportion for unexposed urediniospores) was a linear function of solar irradiance $\left(R^{2}=0.83\right)$ and UV measurements predicted normalized germination proportions equally well. 
Spore deposition - Following the definition of Gregory (1973), fungal spore deposition occurs by means of two processes: gravitational settling and turbulence (dry deposition) and washed out of the air by rain (wet deposition). The latter method of wash out may be more critical for ASR epidemics because the wash out effect can result in the accumulation of spores on a host during favorable leaf wetness and cloud cover conditions conducive to plant infection (Aylor, 1986).

\section{METEOROLOGICAL FACTORS AFFECTING EPIDEMIOLOGICAL (MONOCYCLIC) COMPONENTS}

Fungal infection - The infection process is made of a sequence of events that culminate with the penetration of the fungus into the epidermal cells and confirmation of successful infection by the presence of lesions a few days later. For uredospore germination to occur on plant surfaces, free water is necessary. After landing on a wet leaf surface, ASR spores will germinate and form a germ tube that will grow over the leaf and form an appressoria. Each of these processes may be stimulated by different conditions. Under wet conditions, spore germination initiates in a minimum of one hour and will cease at six to eight hours (Melching et al., 1989; Alves et al., 2006). If moisture is not limiting, spore germination is most strongly affected by temperature.

Melching \& Bromfield (1975) found that temperatures below $9^{\circ} \mathrm{C}$ or above $28^{\circ} \mathrm{C}$ did not favor germination of uredospores on water agar and that the optimum temperature for germination was from 12 to $21^{\circ} \mathrm{C}$. In contrast, Alves et al. (2006) found that uredospores of $P$. pachyrhizi isolates from Brazil germinated at all temperatures ranging from 8 to $30^{\circ} \mathrm{C}$ and that the optimum temperatures for germination varied from 15 to $25^{\circ} \mathrm{C}$. These results agreed with Tan et al. (1996), who showed that the optimum temperature range for uredospore germination in China was 15 to $26^{\circ} \mathrm{C}$. Also, in a study from India, minimum, optimum and maximum temperatures for spore germination were 20,25 and $30^{\circ} \mathrm{C}$, respectively (Singh \& Thapliyal, 1977). In a recent study, a comparison was made among four isolates of $\mathrm{P}$. pachyrhizi, one each from Taiwan, Zimbabwe, Hawaii, and Brazil to determine the effect of temperature on urediniospore germination and germ-tube growth (Bonde et al., 2007). The authors showed that all isolates behave similarly as to how temperature affects urediniospore germination, germ-tube growth and initiation of infection, in spite of the fact that they had been collected from different parts of the world over a period of 21-year period. The optimum temperature for all those processes ranged from 17 to $28^{\circ} \mathrm{C}$.
Koch \& Hope (1987) have shown that while germination of $P$. pachyrhizi was not significantly affected by light, germ tube emergence and growth showed light dependent reactions when the germinating spores were unilaterally irradiated with polychromatic light. For example, germination never occurred through a pore in the cell wall facing the light source. Also, germ tubes always emerged from the shadowed side of the spores and would grow away from the light source when the direction of irradiation was changed during germ tube development (negative phototropism).

Appressoria formation can occur within two hours and ceases after five hours on water agar (Bonde et al., 1976). In another study using a polystyrene surface, appressoria formation initiated after four hours at optimum temperature conditions (18 to $23^{\circ} \mathrm{C}$ ) and no appressoria was formed when temperatures were above $30^{\circ} \mathrm{C}$ (Alves et al., 2006). New information on the timeline of spore germination, appressoria formation and penetration was presented by Vélez-Climent \& Dufault (2007), who verified that, under ideal conditions, uredospores following inoculation and incubation can start: adhering to soybean leaves as soon as $0.5 \mathrm{~h}$; forming appressoria after $3 \mathrm{~h}$ and penetrating the leaves after 12 hours.

The relationships between the establishment of P. pachyrhizi infections, moisture availability on plant surfaces, and temperature have been investigated in growth chambers and greenhouse studies (Marchetti et al., 1976; Melching et al., 1989; Caldwell et al., 2005; Alves et al., 2006). It has been shown that a minimum of 6 hours of moisture is required for infection to occur at $24^{\circ} \mathrm{C}$ (Kitani \& Inoue, 1960). At 18 or $26.5^{\circ} \mathrm{C}$ (Marchetti et al., 1976; Melching et al., 1989 ) increasing periods of wetness are required for infection to occur. Temperatures above $28^{\circ} \mathrm{C}$ were detrimental to infection (Melching \& Bromfield, 1975; Marchetti et al., 1976). Tan et al. (1996) reported that the optimum temperature range for infection was 22 to $26^{\circ} \mathrm{C}$, and confirmed that no infection occurred at $28^{\circ} \mathrm{C}$ or higher. From experiments in South Africa, no P. pachyrhizi infection was found when incubating inoculated plants at temperatures below 15 or greater than $30^{\circ} \mathrm{C}$ (Caldwell et al., 2005). Kochman (1979) found that a 17 to $27^{\circ} \mathrm{C}$ temperature regime was clearly more favorable for rust infection and development than the $22-32^{\circ} \mathrm{C}, 12-22^{\circ} \mathrm{C}$ and $7-17^{\circ} \mathrm{C}$.

Fungal colonization (latent period) - After a successful infection, incipient lesions can be macroscopically discerned within a few days post-inoculation on plants, and the length of time appears strongly influenced by temperature (Bromfield, 1984). In comparison to other rusts, only a small portion $(15 \%)$ of the 
lesion area is comprised of sporogenous tissue (Melching et al., 1979). In Kochman's (1979) study on the effect of temperature on ASR development, a shorter generation time and increasing sporulation was observed when the 17 to $27^{\circ} \mathrm{C}$ temperature regime was used. In an experiment from South Africa, the number of pustules per lesion, as well as lesion size increased with increasing leaf wetness duration at 85 and $95 \% \mathrm{RH}$. At $85 \% \mathrm{RH}$, lesion size on both the leaf surfaces increased after $12 \mathrm{~h}$ leaf wetness at $21^{\circ} \mathrm{C}$. However, at $95 \% \mathrm{RH}$, lesion size only increased after $14 \mathrm{~h}$ leaf wetness at $24^{\circ} \mathrm{C}$ (Caldwell et al., 2005). Alves et al. (2006) did not find differences in lesion size as influenced by the interaction of leaf wetness duration and temperature.

\section{OVERALL EFFECTS OF METEOROLOGICAL FACTORS ON FIELD EPIDEMICS}

There is much less quantitative information on the effect of environmental and meteorological conditions in the field when compared to the body of literature from growth chamber and greenhouse studies. The largest body of information came from field experiments that studied ASR epidemics in Taiwan during the 1980s (Tschanz et al., 1984). In studies conducted in 1979-1980 and 1980-1981, ASR epidemics were related to the mean night temperatures (mean of bi-hourly averages from $10 \mathrm{~h} 00 \mathrm{p}$.m. to $6 \mathrm{~h} 00 \mathrm{a}$ a.m. the next morning). The lowest mean daily night temperatures usually occurred from mid-December to earlyFebruary (around $14^{\circ} \mathrm{C}$ ) and were highest from early June to early September. No rust was observed in the field before early February for plots planted three months earlier. The lower temperatures after mid-December also affected rust development in plots that were planted in late October 1980. Tschanz et al. (1984) concluded that soybean rust development was reduced or prevented at mean night time temperatures below $14^{\circ} \mathrm{C}$, similar to previous findings by Casey (1981) in Australia, who observed that mean daily temperature (not mean night temperature) below $15^{\circ} \mathrm{C}$ retarded rust development. In relation to summer temperature, high mean night temperature (approximately $25.5^{\circ} \mathrm{C}$ ) did not appear to affect rust development since the highest number of lesions per plant was observed in early September in plots that were planted in early July (Tschanz et al., 1984). This is in contrast to a field study in Australia (Casey, 1981) where they observed that daily mean temperatures (not mean night) above $27^{\circ} \mathrm{C}$ for extended periods seemed to retard rust development even with adequate free moisture on leaf surface. Moreover, the development of an ASR epidemic in Australia required about $10 \mathrm{~h}$ of leaf wetness during the day, and daily mean temperatures from 18 to $26^{\circ} \mathrm{C}$ (Casey, 1981).
In Taiwan, Tschanz et al. (1984) suggested that the timing of the first rain and the amount of rainfall during the season were key factors affecting ASR epidemic development, at least during dry seasons. A study to determine the effect of rainfall and irrigation on rust development in three planting dates over two years showed that both factors were important. For instance, in the dry fall season of $1979(28.5 \mathrm{~mm}$ in six rainy days during the period of the trial), $1 \%$ ASR severity was observed 72 days after planting in the non-irrigated trial and the rate of rust development was $0.9 \%$ day $^{-1}$, whereas in the overhead irrigated plot, $1 \%$ ASR severity was noticed 58 days after planting and the rate was $2.2 \%$ day $^{-1}$. In the 1980 trials, when moisture was not limiting, date of rust appearance and rate were similar in both irrigated and no irrigated plots. The authors hypothesized that precipitation appeared to be necessary for rust development even when soybean was grown under irrigation. However, during a dry season, irrigation did alter timing of disease onset and epidemic rate (Tschanz et al., 1984).

Another strong piece of evidence that rain may influence an ASR epidemic was based on a series of epidemics that were recorded at several locations in China in the 1970s and early 1980s (Tan, 1996). Several rainfall based linear functions were developed to predict maximum seasonal ASR severity for different locations in the country based on the accumulated rain amount and the number of rainy days in a calendar month (either September, October, or both) during an epidemic. Predictions based on the regression models closely match the observed disease index (disease index rating from 1 to 5) (Tan, 1996).

Recently, maximum disease severity was related to different rain variables based on the analysis of thirty-four ASR field epidemics (i.e., not inoculated) at 21 sites from southern to northern soybean regions in Brazil over three growing seasons (2002/03 to 2004/ 05) (Del Ponte et al., 2006b). The authors verified a strong correlation between rainfall patterns in a 30-day window following disease detection from which regression models were developed to predict maximum disease severity. Two rainfall models, the first a second-order linear model using only accumulated rainfall for the 30-day period following disease detection, and the second, a first-order linear regression model that used the same predictor variable as the first model, but also the number of rainy days over the same period, had highest predictive accuracy and lowest prediction errors. Low values for maximum disease severity were found for locations in southern regions of Brazil (latitude $>23^{\circ}$ ), where relatively longer dry periods were recorded, and where minimum temperature was lower during the growing season compared to 
northern locations. Del Ponte et al. (2006b) found a weak correlation between temperature variables and maximum disease severity for the same 30-day period, suggesting that temperature range in most of Brazilian regions is not limiting for epidemic development.

In Africa, there is also empirical evidence regarding the influence of rain in field epidemics. In Uganda, Kawuki et al. (2004) showed that rainfall, especially during mid-growth period of the crop, was important for examining soybean cultivar reactions. For example, the authors did not observe any differences among soybean cultivars and their reaction to ASR during a rainy season, when the highest ASR severities and infection rates were observed. In a preliminary testing of the rain models developed with the Brazilian data for predicting ASR severity in Kwazulu-Natal, South Africa over three seasons of observations based on different soybean planting dates per season, there were good agreements between the predicted and observed severity, thus further confirming that rain is a key factor for ASR epidemic development (Del Ponte et al., 2005).

Studies on ASR epidemic patterns at regional levels are limited mostly to the description of epidemic progress over time and space at a large scale (Christiano $\&$ Scherm, 2007). However, there is preliminary qualitative and quantitative analyses on the relationship between both regional epidemic onset and progress rate and the seasonal rainfall amount and distribution (Esker et al., 2006; Esker et al., 2007).

\section{METEOROLOGICAL FACTORS AND ASR FORE- CASTING}

The information on the effect of meteorological factors on epidemiological and aerobiological components of ASR can be expressed in the form of mathematical functions or rules that use single or combined factors as predictor variables. Several ASR forecasting systems use such information individually or integrated to predict ASR risks in real-time during the season or assess the risks under different climate scenarios (Del Ponte et al., 2006a). The issues regarding the use of weather variables for predicting ASR risks relate to the type of variable, time and spatial scales.

Most disease forecasting models developed are aimed at predicting epidemiological components with the main climatic and weather-related variables being temperature, relative humidity, leaf wetness and rainfall. Recently, wind speed, wind direction, and solar radiation have been used in the aerobiological models for ASR forecasting (Isard et al., 2005; Pan et al., 2006). Historically, the first ASR epidemiological models used hourly measurements of leaf wetness duration and temperature during the wet period (Yang et al., 1991b). Since those variables influence infection (Figure 1), it is reasonable to use those models when the goal is forecast the risk of infection (Reis et al., 2004; Canteri et al., 2005) or to integrate them into a mechanistic approach for predicting disease severity increase from multiple secondary infections (Yang et al., 1991b). Thus, the types and number of weather variables used for ASR forecasting are strongly dependent on the approach and the disease component estimated. For instance, the aerobiological framework for predicting ASR epidemics in the United States (Isard et al., 2005) requires an extensive collection of weather-related variables because the mechanistic nature of this model estimates several aerobiological and epidemiological components simultaneously. In this approach, new information on the effect of solar radiation on spore survival (Isard et al., 2005) appears to be important factor for accurate predictions using aerobiological models, since long-distance dispersal of ASR spores have been recently confirmed (Krupa et al., 2006). Preliminary information on the effect of artificial shading favoring ASR establishment in the field (Dias et al., 2007) may relate to the negative effect of direct sunlight and its effect on spore germination. Since high rainfall frequency and cloud cover are correlated, it is possible that shading might be another indirect effect of rainfall, among other effects suggested by Del Ponte et al. (2006b).

Further research is needed to increase our understanding of the effect of scaling weather variables monitored at one scale and used to predict the risk of ASR at a different scale (Clark, 2005; Banerjee et al., 2004; Urban, 2005). For example, this may mean the use of regional temperature to predict the risk of ASR at a field scale, or the use of site-specific information obtained at the field-scale to predict risk at a municipality scale. This is a topic that has been discussed across scientific disciplines and has been named differently as a result: ecological fallacy (sociology and ecology), Simpson's paradox (statistics), modifiable area unit problem (geography), or change of support (geostatistics) (Agresti, 2002; Banerjee et al., 2004; Cressie, 1993; Waller \& Gotway, 2004). What does this mean with respect to ASR? As an example, if we have the rainfall amounts that can be related with ASR development obtained at the field level, how reliable is it to use an average value for the municipality when rainfall pattern is not uniform over the region? There is variation in this observation at the field level and it is very possible that error magnification (synonym, error propagation) may occur, reducing prediction accuracy. Because of the extensive interest in risk prediction at different scales (e.g., field, region, conti- 
nent), ASR is an excellent system to examine the uncertainty in using weather variables observed at one scale and predicting the risk of an epidemic at another scale. Currently, both computational and statistical methods exists (Clark, 2005) that can help to determine the role of scaling in predicting the risk of ASR and has been recently a topic of interest in plant pathology.

\section{FINAL REMARKS}

Although there is considerable amount of information on the effects of meteorological factors affecting the disease in a controlled environment, the extrapolation of results from this situation, and using them to predicting disease occurrence in the field can be problematic, since the characteristics and the dynamic nature of a crop canopy may affect how epidemics develop in the field quite differently from a controlled environment. Differences between air temperature above or outside the canopy (the common temperature measure inputted into forecasting models) and leaf temperature inside the canopy where the ASR infection begins may be quite different. Currently, this information is lacking. Empirical evidence indicates that severe ASR epidemic levels occur in regions in Brazil where daytime air temperature is higher than the upper limits found under controlled conditions (Del Ponte et al., 2006b). Thus, it is important to conduct research that examines the variability in temperature within the soybean canopy.

While moisture variables (e.g. leaf wetness) are key factors in the infection process, there is great debate regarding the importance of the source of moisture (dew versus rainfall). While it appears that rainfall is a driving variable to speed up ASR epidemics in the field and promoting regional spread, the direct or indirect biological role of rain in the epidemic process requires further investigation. It is still unknown whether environmental factors (lower temperature or lower rainfall) affect the severity of epidemics in the higher latitudes of both South and North America, where epidemics also occur later in the growing season. Also, there is uncertainty on what is limiting severe epidemics in locations at higher altitudes in Brazil, where ASR epidemics were previously suggested to be severe given the abundance of dew, especially in southern Brazil. So far, most severe epidemics occur in high rainfall areas and the disease development seems to be sensibly affected by relatively long dry periods that are common in southern Brazil.

There is clearly much less information regarding the meteorological factors that affect the aerobio- logical phase of the ASR epidemic than the aerobiological one. Recent observations by Krupa et al. (2006) indicated that ASR spores were present in the early to mid-season soybean periods in the northern US (no disease was observed), thus proving that spores are capable of long distance, movement. But, which meteorological factors may be affecting spore viability during transport is currently lacking. The information is crucial to increase accuracy of the aerobiological models that predict movement of spores over large distances.

In spite of the occurrence of ASR epidemics over large regions in Brazil in the last five years, there are limited studies that described regional disease spread and examined the factors affecting epidemic development under field conditions over large productions areas, which could aid in the understanding of these processes and provide useful information for regional forecasting systems. Disease forecasting in Brazil are at this far limited to site-specific warning systems using meteorological-based models (temperature $\times$ wetness) and a national monitoring system that alerts on the first occurrence of ASR in a municipality. In both cases, just part of the risk information is being considered. More efforts are necessary to ideally combine information from presence of local inoculum, weather monitoring and forecast and availability of hosts. Comparing with North America, it could be challenging to use aerobiological based models in Brazil since there is no restricted inoculum overwintering area from where the dispersal can be predicted.

While there has been a large body of information obtained regarding recent ASR epidemics, there is still an urgent need to deal with the disease in the field, especially in Brazil where tremendous yield losses have occurred. Since currently the best method of managing the disease is through the use of foliar fungicides, continued refinement of current forecasting models will help to increase the efficacy because the dependence on the correct time and number of application for a disease that can develop very rapidly. Moreover, large scale and long-term predictions are needed to examine the risk of ASR, increasing the ability to be prepared for continued epidemics. But, in order to accomplish that task, a more complete understanding of the key factors that drive an ASR epidemic is crucial.

\section{ACKNOWLEDGEMENTS}

We thank the financial support from the National Science Foundation (U.S.) Division of Biological Informatics (DBI-0630726). 


\section{REFERENCES}

AGRESTI, A. Categorial data analysis. 2 ed. Hoboken: WileyInterscience, 2002. 710p.

ALVES, S.A.M.; FURTADO, G.Q.; BERGAMIN FILHO, A. Influência das condições climáticas sobre a ferrugem da soja. In: ZAMBOLIM, L. (Org.) Ferrugem asiática da soja. Visconde do Rio Branco: Suprema Gráfica e Editora, 2006. p.37-59.

AYLOR, D.E.; FERRANDINO, F.J. Escape of urediniospores of Uromyces phaseoli from a bean field canopy. Phytopathology, v.75, p.1232-1235, 1985.

AYLOR, D.E. A framework for examining inter-regional aerial transport of fungal spores. Agricultural and Forest Meteorology, v.38, p.263-288, 1986.

BANERJEE, S.; CARLIN, B.P.; GELFAND, A.E. Hierarchical modeling for analysis for spatial data. Boca Raton: CRC Press, 2004. 472p.

BECK, L.F.; MILES, M.R.; STEILAGE, T.A.; HARTMANN, G.L. Urediniospore release and escape from rust-infected soybean fields. In: NATIONAL SOYBEAN RUST SYMPOSIUM, St. Louis, 2006. Proceedings. St. Paul: APS, 2006. Available at: http://www.plantmanagementnetwork.org/infocenter/topic/ soybeanrust/2006/posters/38.asp. Accessed 4 Mar. 2007.

BONDE, M.R.; MELCHING, J.S.; BROMFIELD, K.R. Histology of the suscept-pathogen relationship between Glycine max and Phakopsora pachyrhizi, the cause of soybean rust. Phytopathology, v.66, p.1290-1294, 1976.

BONDE, M.R.; BERNER, D.K.; NESTER, S.E.; FREDERICK, R.D. Effects of temperature on urediniospore germination, germ tube growth, and initiation of infection in soybean by Phakopsora isolates. Phytopathology, v.97, p.997-1003, 2007.

BROMFIELD, K.R. Soybean rust. St. Paul: American Phytopathological Society, 1984. 65p. (Monograph, 11).

CALDWELL, P.M.; NUNKUMAR, A.; PRETORIUS, Z.A.; FERNANDES, J.M.C. Development of Phakopsora pachyrhizi at different temperatures, relative humidities and leaf wetness duration. In: INTERNATIONAL WORKSHOP ON PLANT DISEASE EPIDEMIOLOGY, 9., Landerneau, 2005. Proceedings. 2005. Bordeaux: Societé Francaise de Phytopathologie, 2005. Abstract C3.

CANTERI, M.G.; CARAMORI, P.; TSUKAHARA, R.; SILVA, O.C.; FARIA, R.; GODOY, C.V. A system to map risk of infection by Phakopsora pachyrhizi for Paraná State, Brazil. Phytopathology, v.95, p.S16, 2005.

CASEY, P.S. The epidemiology of soybean rust: Phakopsora pachyrhizi Syd. Soybean Rust Newsletter, v.4, p.3-5, 1981.

CHRISTIANO, R.C.S.; SCHERM, H. Quantitative aspects of the spread of Asian soybean rust in the southeastern United States, 2005 to 2006. Phytopathology, v. 97, p.1428-1433, 2007.

CLARK, J.S. Why environmental scientists are becoming Bayesians. Ecology Letters, v.8, p.2-14, 2005.

CONSÓRCIO ANTIFERRUGEM. Available at: http:// www.consorcioantiferrugem.net. Accessed 25 Oct. 2007.

CRESSIE, N.A.C. Statistics for spatial data. New York: John Wiley, 1993. 928p.

DEL PONTE, E.M.; GODOY, C.V.; DUPREEZ, E.D.; VANRIJ, N.C.; CALDWELL, P.M.; YANG, X.B. Predicting regional Asian soybean rust outbreaks in Brazil and South Africa. Phytopatology, v.95, p.S23, 2005.

DEL PONTE, E.M.; GODOY, C.V.; CANTERI, M.G.; REIS, E.M.; YANG, X.B. Models and applications for risk assessment and prediction of Asian soybean rust epidemics. Fitopatologia Brasileira, v. 31, p.533-544, 2006a.

DEL PONTE, E.M.; GODOY, C.V.; LI, X.; YANG, X.B. Predicting severity of Asian soybean rust with empirical rainfall models. Phytopathology, v.96, p.797-803, 2006b.

DIAS, A.S.; HARMON, P.F.; HARMON, C.L.; YANG, X.B. Effects of light intensity and time on the incidence and severity of Asian soybean rust. Phytopathology, v.97, p.S28, 2007.
ESKER, P.; DEL PONTE, E.M.; YANG, X.B. Epidemiological factors influencing regional establishment of Asian soybean rust in Brazilian soybean areas. Phytopathology, v.96, p.S33, 2006.

ESKER, P.D.; DEL PONTE, E.M.; MARTINS, M.; KATO, M.; SIQUERI, F.V.;SILVA, L.H.; GODOY, C.V. Effects of location and year on the temporal disease progress of Asian soybean rust in Brazil. Phytopathology, v.97, p.S33, 2007.

GODOY, C.V. Resultados da rede de ensaios para controle químico de doenças na cultura da soja: safra 2003/2004. Londrina: Embrapa Soja, 2005. 88p. (Documentos, 251),

GREGORY, P.H. The microbiology of the atmosphere. New York: Wiley, 1973. 377p.

ISARD, S.A.; DUFAULT, N.S.; MILES, M.R.; HARTMAN, G.L.; RUSSO, J.M.; DE WOLF, E.D.; MOREL, W. The effect of solar irradiance on the mortality of Phakopsora pachyrhizi urediniospores. Plant Disease, v.90, p.941-945, 2006.

ISARD, S.A.; GAGE, S.H.; COMTOIS, P.; RUSSO, J.M. Principles of the atmospheric pathway for invasive species applied to soybean rust. Bioscience, v.55, p.851-861, 2005.

IVANCOVICH, A. Soybean rust in Argentina. Plant Disease, v.89, p.667-668, 2005.

KAWUKI, R.S.; ADIPALA, E.; TUKAMUHABWA, P. Yield loss associated with soya bean rust (Phakopsora pachyrhizi Syd.) in Uganda. Journal of Phytopathology, v. 151, p.7-12, 2004.

KEMERAIT, R.C.; SCONYERS, L.E.; JOST, P.H.; MILLS, W.A. Evaluation of fungicides for control of Asian soybean rust in Attapulgus, Georgia, 2005. Fungicides \& Nematicides Tests, v.61, p.FC072, 2006.

KITANI, K.; INOUE, Y. Studies on the soybean rust. Bulletin of the Shikoku Agriculture Experimental Station, v.5, p.319342,1960 .

KOCH, E.; HOPPE, H.H. Effect of light on uredospore germination and germ tube growth of soybean rust (Phakopsora pachyrhizi Syd.). Journal of Phytopathology, v.119, p.64-74, 1987.

KOCHMAN, J.K. The effect of temperature on development of soybeans rust (Phakopsora pachyrhizi). Australian Journal of Agricultural Research, v.30, p. 273-277, 1979

KRUPA, S.; BOWERSOX, V.C.; CLAYBROOKE, R.D.; BARNES, C.W.; SZABO, L.J.; HARLIN, K.S.; KURLE, J.E. Introduction of Asian soybean rust urediniospores into the midwestern United States: a case study. Plant Disease, v.90, p.1254-1259, 1996.

LEVY, C. Epidemiology and chemical control of soybean rust in southern Africa. Plant Disease, v.89, p.669-674, 2005.

MARCHETTI, M.A.; UECKER, F.A.; BROMFIELD, K.R. Uredial development of Phakopsora pachyrhizi in soybean. Phytopathology, v.65, p.822-823, 1975.

MARCHETTI, M.A.; MELCHING, J.S.; BROMFIELD, K.R. The effects of temperature and dew period on germination and infection by urediospores of Phakopsora pachyrhizi. Phytopathology, v.66, p.461-463, 1976.

MELCHING, J.S.; BROMFIELD, K.R. Factors influencing spore germination and infection by Phakpsora pachyrhizi and intensification and spread of soybean rust under controlled conditions. Proceedings of the American Phytopathological Society, v.2, p.125, 1975 .

MELCHING, J.S.; DOWLER, W.M.; KOOGLE, D.L.; ROYER, M.H. Effects of duration, frequency, and temperature of leaf wetness periods on soybean rust. Plant Disease, v.73, p.117 122,1989

MELCHING, J.S.; BROMFIELD, K.R.; KINGSOLVER, C.H. Infection, colonization, and uredospore production on Wayne soybean by four cultures of Phakopsora pachyrhizi, the cause of soybean rust. Phytopathology, v.69, p.1262-1265, 1979

ONO, Y.; BURITICA, P.; HENNEN, J.F. Delimitation of Phakopsora, Physopella and Cerotelium and their species on Leguminosae. Mycological Research, v.96, p.825-850, 1992.

PAN, Z.; YANG, X.B.; PIVONIA, S.; XUE, L.; PASKEN, R; ROADS, J. Long-term prediction of soybean rust entry into the continental United States. Plant Disease, v.90, p.840-846, 2006.

Sci. Agric. (Piracicaba, Braz.), v.65, special issue, p.88-97, December 2008 
PIVONIA, S.; YANG, X.B. Assessment of potential year round establishment of soybean rust throughout the world. Plant Disease, v.88, p.523-529, 2004.

REIS, E.M.; SARTORI, A.F.; CAMARA, R.K. Modelo climático para a previsão da ferrugem da soja. Summa Phytopathologica, v.30, p.290-292, 2004.

ROSSI, R.L. First report of Phakopsora pachyrhizi, the causal organism of soybean rust in the Province of Misiones, Argentina. Plant Disease, v.87, p.102, 2003.

SCHNEIDER, R.W.; HOLIER, C.A.; WHITAM, H.K.; PALM, M.E.; McKEMY, J.M.; HERNANDEZ, J.R.; LEVY, L.; DEVRIESPATERSON, R. First report of soybean rust caused by Phakopsora pachyrhizi in the continental United States. Plant Disease, v. 89, p.774, 2005.

SCONYERS, L.E.; KEMERAIT, R.C.; BROCK, J.; PHILLIPS, D.V.; JOST, P.H., SIKORA, E.J.; ESTRADA, A.G.; MUELLER, J.D.; MAROIS, J.J.; WRIGHT, D.L.; HARMON, C.L. Asian soybean rust development in 2005: a perspective from the Southeastern United States. 2006. Available at: http://www.apsnet.org/online/ feature/sbr/. Accessed 1 Jan. 2008.

SINCLAIR, J.B.; HARTMAN, G.L. Soybean diseases. In: HARTMAN, G.L.; SINCLAIR, J.B.; RUPE, J.C. (Ed.) Compendium of soybean diseases. 4 ed. St. Paul: American Phytopathological Society, 1999. p.3-4.

SINGH, K.P.; THAPLIYAL, P.N. Some studies on the soybean rust caused by Phakopsora pachyrhizi. Indian Journal of Mycology and Plant Pathology, v.7, p.27-31, 1977.

TAN, Y.J.; YU, Z.; YANG, C.Y. Soybean rust. Beijing: China Agricultural Press, 1996. 99p.

TSCHANZ, A.T. Soybean rust epidemiology: final report. Shanhua: Asian Vegetable Research and Development Center, 1984. 157p.

URBAN, D.L. Modeling ecological processes across scales. Ecology, v.86, p.1996-2006, 2005.

VÉLEZ-CLIMENT, M.C; DUFAULT, N. The adhesion and rainfall washoff of urediniospores on soybean leaves. In: NATIONAL SOYBEAN RUST SYMPOSIUM, Louisville, 2007. Proceedings. Available at: http://www.plantmanagementnetwork.org/ infocenter/topic/soybeanrust/2007/presentations/Dufault.pdf. Accessed 10 Jan. 2008.
WALLER, L.A.; GOTWAY, C.A. Applied spatial statistics for public health data. Hoboken: Wiley-Interscience, 2004. 494p.

YANG, X.B.; ROYER, M.H.; TSCHANZ, A.T.; TSI, B.Y. Analysis and quantification of soybean rust epidemics from seventythree sequential planting experiments. Phytopathology, v.80, p.1421-1427, 1990.

YANG, C.Y. Past and present studies of soybean rust incited by Phakopsora pachyrhizi Syd. Bulletin of the Institute of Tropical Agriculture, v.2, p.78-94, 1977.

YANG, X.B.; DOWLER, W.M.; ROYER, M.H. Assessing the risk and potential impact of an exotic plant disease. Plant Disease, v.75, p.976-982, 1991a.

YANG, X.B.; DOWLER, W.M.; TSCHANZ, A.T. A simulation model for assessing soybean rust epidemics. Journal of Phytopathology, v.133, p.187-200, 1991b.

YORINORI, J.T.; PAIVA, W.M.; FREDERICK, R.D.; COSTAMILAN, L.M.; BERTAGNOLLI, P.F.; HARTMAN, G. L.; GODOY, C.V.; NUNES-JÚNIOR, J. Epidemics of Soybean rust (Phakopsora pachyrhizi) in Brazil and Paraguay from 2001 to 2003. Plant Disease, v.89, p.675-677, 2005.

YORINORI, J.T. Asiatic rust of soyabean (Phakopsora pachyrhizi): occurrence in Brazil and management strategies. Londrina: Embrapa Soja, 2002. p.73-83. (Documentos, 186).

ZIDEK, J. Phakopsora pachyrhizi urediniospore scape from a soybean canopy. State College: Pennsylvania State University, 2007. 125p. (M.S.).

Received November 01, 2007

Accepted July 28, 2008 